\section{The Inflexible Nature of Federalism}

\section{By Geoff Nelson*}

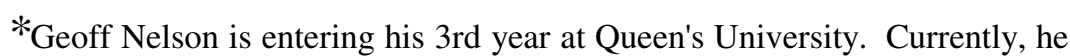
is in an honours Bachelor of Science program with a major in Chemistry and a minor in Political Science. It is his goal to enter a graduate program in either Public Administration or Chemistry.

\section{Résumé}

L'inflexibilité est une faiblesse fondamentale des systèmes fédéraux. Le fédéralisme est marqué par une rigidité constitutionnelle, plus particulièrement par une formule d'amendement stricte et une séparation de pouvoirs conflictuelle. L'auteur illustre cette inflexibilité avec les exemples des relations entre les autochtones et les régimes fédérales Canadiens, Australiens et Américains.

"It is a common criticism of federal government that it is too rigid, too conservative, too difficult to alter; that it is consequently behind the times" (Wheare 209).

The twentieth century has generally been a time of prosperity and it has brought to light the strength and dominance of liberal democracy into our political culture. In particular, it has lead to the success of the engine of liberal democracy, federalism. However, like all engines there are inherent weaknesses within the structure that exist from conception and perpetuate over time. Australia, Canada and the United States are federations who share a common weakness: inflexibility. The weaknesses of an engine can sometimes be invisible for a long time, and it usually requires a catalyst to be seen. In these three federations, one such catalyst has been the federal system's relationship with Aboriginals. A fundamental weakness of federalism is that it is inflexible. Nowhere is this clearer than in federalaboriginal relationships in Canada, Australia and the United States.

This discussion will begin by first defining federalism and indicating the terminology that will be used. Following this will be a brief explanation for choosing evidence from Australia, Canada, and the United
States, based upon their similar federal systems. The inflexible elements of federalism are the properties of a rigid constitution: a strict amending formula and a conflict prone separation of powers. Entrenched amending processes limit constitutional change. The examples of failed attempts by Aboriginals to force amendments, which would have recognized their unique status, will be used to show that this is the case. Federal systems are characterized by a separation of power and territorial jurisdiction between two levels of government. This structure is inflexible because it does not allow either level of government, once created, to concede power or territory. Again, through various aboriginal experiences, such as the movement to create a third-order of government, the inflexible nature of the second property of federalism will be demonstrated. Combined, the two rigid properties of a federal constitution are not conducive to change.

There are many opinions of what embodies federalism and what should be included in its definition. Furthermore, recent diverging definitions have been introduced to the political scene, such as "executive federalism", "fiscal federalism" and "quasi federal". In this discussion, Ronald Watt's notion of federalism will be adopted as the general definition of the terms federalism, federation, federalist and federal system:
a) [having] two orders of government each acting directly on their citizens ${ }^{1}$,
b) [having] a formal constitutional distribution of legislative and executive authority and allocation of revenue resources between the two orders of government ensuring some areas of genuine autonomy for oach order; and

c) [having] a supreme written constitution not unilaterally amendable and requiring the consent of a significant proportion of the constituent units (Watts $6)$

This discussion's main thrust is based on the constitutional element of federalism and the property of power distribution. Despite this limitation, the reader should be aware of the fluidity of this definition. This occurs because each element is linked to the usage of a constitution, due to the fact

${ }^{1}$ It should be noted that in the three jurisdictions that will be discussed, the two levels of government are referred to as the federal level (national) and the regional level (states, provinces, territories). 
that principles of structure, divisions of power and autonomy are all defined, in different states, by their respective constitutions.

Canada, Australia and the United States have been chosen as our model countries for two reasons: 1) all three countries have been recognized as states that have opted to use the basic "federal solution" for their governments $(\text { Scott } 1)^{2}$, and 2) prior to the colonization of each of the three countries, there were indigenous people inhabiting their respective territories. In Canada, they include the Inuit in the North and other Native Canadian groups; the United States refers to its aboriginals as Native Americans, or "American Indians" while the Australians have shared their continent with the Aborigines. The relationships between these indigenous people and the government of each jurisdiction will be addressed to help understand points made during this argument.

Federal systems employ the use of a constitution to structure government. These constitutions can be flexible or rigid based on the supremacy that the constitution has over other laws that are made by the state. A flexible constitution is defined as one that can be changed in the same manner as other laws while a rigid constitution can only be amended by a different method (Wheare 209). According to Wheare, federal constitutions, such as those employed by Canada, Australia and the United States are classified as rigid constitutions, because they are intended to "reign supreme over the legislatures - [national] and regional" (Wheare 209). The methods used by these federal systems to change the constitution can be classified as either a qualified majority approach or a unanimous consent approach and any situation that requires those methods cannot be simply legislated into effect (Johnston 282-3). One or the other is needed in order to amend the constitution; the difficulty in acquiring the support of a qualified majority, let alone the unanimous agreement of national and subnational governments, makes these constitutions rigid. Metaphorically, the amendment procedures bind the hands of the government and hence severely limit what the government can do.

The two amending formulae used by these three countries are the unanimous consent and qualified majority methods. Unanimous consent is required in certain situations, such as proposed amendments concerning the monarchy in Canada and Australia, in order to effect change. However, "given the unanimity of requirement necessary, it is extremely doubtful that

\footnotetext{
2 Despite Canada and Australia having parliamentary systems, compared to the United States' presidential system, they share the common elements of federal countries outlined by Johnson.
}

significant change could occur" (Meekison 74). This quote recognizes that there is a diversity of opinion surrounding each amendment requiring unanimous consent, and this makes it difficult to achieve perfect consensus on amendment issues. The daunting task of attaining such consent means that unanimous consent is reserved for situations that would fundamentally change the political landscape of the state. To this date, in both Canada and Australia-despite a recent election that considered the question of republicanism in Australia - unanimous consent has never been reached.

The qualified majority method has also proven to be a difficult standard of consent to achieve. In the United States "all amendments [must be] passed by a qualified majority of both houses of [the national government] and the [states]" (Verney 94). The same is true of Canadafor those not covered by section 39 of the constitution-and Australia. In Australia's case, amendments were proposed 23 times between 1901 and1963, and only four of these amendments had the required qualified majority conditions ${ }^{3}$. In the Canadian situation, there have been two attempts to change the constitution since 1982; Meech Lake and Charlottetown both failed, in diverging ways to

meet the required qualified majority of support ${ }^{4}$. In the United States, 27 amendments have been made to the constitution; however, six are still outstanding and there have been 10,000 other proposed amendments that have failed to gain the needed qualified majority (Wheare 282$)^{5}$. The above examples demonstrate the rarity of a successful qualified majority, let alone unanimous consent. The constitutions of these three countries limit the ability of government to effect significant change.

The Charlottetown Accord is a unique Canadian document because it represented a potential agreement by the federal, the provincial and aboriginal leaders that could have fundamentally changed the nature of

\footnotetext{
${ }^{3}$ The conditions for the amendments mentioned are: "the requisite majority of all electors voting and of a majority of electors in a majority of states" (Wheare 210).

${ }^{4}$ Section 38 of the Constitution Act, 1982 requires that these amendments require: "a) resolutions of the Senate and House of Commons; and b) resolutions of the legislative assemblies of at least two-thirds of the provinces that have, in the aggregate, according to the then latest general census, at least fifty per cent of all the population of all the provinces (Johnston 283).

${ }_{5}$ There are two methods for amending the constitution of the United States. One of these two methods, according to Johnston has never been used. Normally, a constitutional amendment in the United States must receive a two-thirds vote in both houses of Congress and must be ratified by three-quarters of the states, usually through the legislatures.
} 
Canadian government. It was agreed by all parties that this was a necessary step towards - a better life for aboriginal peoples in Canada. However, the results of a national referendum did not support the changes being proposed (Charleton 79). The minority that supported this accord, in particular the First Ministers and the aboriginal leaders, could not effect change if the public did not accept it, despite its merits. This is the cruel nature of federalist constitutions, as it binds government to the will of the majority, whether the government does not-or in this case did-support the amendment. The concept of majority is an integral part of the qualified majority concept both in definition and in principle. It has been shown that the rigid constitutions of federal systems are a weakness, due to the dependency of significant change on the amending formulas entrenched within federal constitutions. In the end, this only exacerbates the overall inflexible nature of federalism.

The constitutions of federal states also dictate the structure of government. As stated in the definition, this structure is that of a national government with regional governments. In Canada, Australia and the United States, there is only one level of regional government, that being provinces for the first two and states for the latter. This system is inflexible because it does not provide room for either level, once created, to concede power or territory. Also, the autonomy of the two levels encourages intergovernmental quarrels that only serve to delay action, and thus contribute to the overall rigidity of the federal system.

Federal governments have self-autonomous powers within their territorial jurisdiction. Wheare believes that "the provinces and the states are reluctant to give up jurisdictions (240)." The same comment could be extended to the national level of government for federations. The need to maintain their respective control is great and consequently, there is an ongoing difference of opinion regarding which powers should be delegated to the national and sub-national governments. The inflexible aspect of this struggle for power occurs when there is an issue of interest to both levels of government.

In Australia, the national government, based on an amendment to the constitution in 1967, had the ability to make "special laws" for aboriginals. However, "the commonwealth may have jurisdiction to make laws which override state legislation on Aborigines, but it has no room to maneuver if other jurisdictions are involved" (Charmann 191). In one intergovernmental conflict, the regional government of Queensland converted two aboriginal missions within their territory into "local government areas" (Charmann 191). Essentially, the states used their powers to create local government areas to change the jurisdiction of the region and thus made the federal government's power irrelevant within that area. This new jurisdiction was one in which the national government could not establish their special laws and thus prevented action from occurring. Irrespective of the potential impact these laws may have had, this example indicates that the power of autonomy of each level of government is in continual conflict-these conflicts create situations of inaction. Furthermore, this example demonstrates the tendency of governments to expand their jurisdiction, both territorial and in legal power. Bluntly put, federal systems are known for the "bewildering maze of legal maneuvering" (Nichols 291), and, like many mazes, those involved are bound to get lost. The powers of autonomy and the expansion of related powers invested in the two levels of government cause conflicts that are not conducive to change.

Another conflict that will demonstrate the inflexibilities caused by the constitutional structure of federalist systems is the Canadian question of whether a third order of government should be part of the Canadian federal system. Presently, the Canadian constitution, according to sections 91 and 92, divides the powers of government between the Parliament of Canada and the Provincial Legislatures. At this point, let us assume that any amendment will be able to be passed easily. Even with this assumed flexibility there are boundaries to be crossed. Across Canada there are approximately 600 bands of Aboriginals on 2200 reserves spanning across the country (Flanagan 86). The current notion of third level of government includes both the concept of relinquishing territory and power to the Natives Canadians (Kymlicka 144). The location of these many bands makes this proposal daunting in itself because it will be necessary to "redraw the boundaries of the provinces to create an aboriginal majority" (Flanagan 86).

The boundaries of existing provinces include people, infrastructure and resources that are presumably valuable to provincial governments and that lie within the jurisdiction that is outlined in the constitution. It will be difficult for the national government to persuade the provinces to concede these elements of property to a third order of government. Moreover, both the Meech Lake and Charlottetown Accords demonstrated that some ties to the national government must remain in order to maintain its supreme power over any third level of government (Turpel 120). According to the Charlottetown Accord, it was demanded by the provinces of Alberta, Newfoundland and Quebec that the right of self-government should be subject to federal and provincial laws, and that no new land rights would be made after implication (Turpel 121). Losing legal control of the indigenous population would be an unacceptable concession due to the provinces' need 
to respect the wishes of the majority and the confines dictated by the notion of 'peace, order, and good government', as stated in the constitution. The federal structures that are outlined in federal constitutions guide the governments' actions and they must abide by its principles and legalities. Jurisdiction over territory and the powers, which have been stated in the constitution, are difficult to relinquish by any order of government. The example of an Aboriginal third order of government demonstrates that the structures of federal systems, once entrenched in a written constitution, are inflexible.

The argument that has been presented thus far has been supporting the notion that the properties of federal constitutions contribute to the weakness of federalism, that is, that it is inflexible. However, some may argue that inflexibility is not a fundamental weakness of federalism. Proponents of this claim argue that the existence of an independent judiciary brings an element of flexibility to federalism. They use the examples of the courts rejecting legislation that does not conform to the constitution to partially substantiate the claims that federalism is flexible (Johnston 436). These rejections, it is claimed, allow groups to challenge the rigidity of federalism and effect change. This substantiation will be refuted. In federal systems, an independent judiciary has been known to reject legislation that does not conform to the constitution. However, there have been situations where the rejection or non-rejection of legislation has made federalism less flexible. It has been observed that "in both countries, [Canada and the United States], there have been broad periods in which rulings from the court have tended to favour the expansion of the relative power of one level of government over the other (Johnston 269).

The flow of power from one level to another can drastically affect the relationship between the two levels of government in a federation. These actions can tip the intended power balance between levels of government. In an attempt to oppose an unpopular decision, one only has to pit power against power and the motion will be at least temporarily halted. The evolution of Canada into a decentralized federation and the United States into a centralized federation are examples where courts have changed the balance of power (Johnston 268-269). In 1970, Pierre Trudeau, while reacting to a list of "federal intrusions collected by the Western Premiers' Task Force on Constitutional Trends" by the provinces, accused the provincial governments of "balkanizing the country without regard of the national interest" (Stevenson 43). Court decisions may have flexible consequences, but the evolution of Canada by judicial means has led to a powerful figure in Canadian politics, the Prime Minister, complaining that his ability to function is being limited by this evolution. The intrusions limit the power that the Prime Minister has to effect, regardless of its merits, his political agenda. This Canadian example is not the only one, as the history of the United States and Australia also include examples of the inflexibility caused by federal evolution by judicial means. Although it can be argued that judicial decisions make federalism more flexible, the counter-argument that has just been made suggests that this particular judicial ability can also lead to the exacerbation of the already inflexible properties of federalism.

Federalism is an inflexible form of government. Federal constitutions have stringent amending formulae which restrict the addition of amendments that may improve the state of a federation. Also, the entrenched separation of powers between the two levels of government in a federal system creates conflict and notably obstructs possible progress. This argument was substantiated through the aboriginal experience in Canada, Australia, and the United States. Opponents to the concept that federalism is rigid argue that the judicial element of federalism makes this form of government more flexible. It was demonstrated that the judiciary in federal systems has created inter-governmental imbalances, and consequently 'straight-jackets' the potential to enact political change. This discussion demonstrated that federalism, despite its laurels, is inflexible and this weakness has often been overlooked.

Like all engines, the engine of Federalism will not run forever as long as the weakness of inflexibility persists without a solution. Thomas Paine once said, "government, even in its best state, is but a necessary evil; in its worst state, an intolerable one" (373:1). Federalism is no exception. As our conception of the world changes, it is inevitable that new forms of government will emerge in order to temper the intolerable grievances that are currently present in the various governmental systems. Hopefully, these new forms of government will be able to drive the ship of state with a better maintenance record.

\section{Works Cited}

Charleton, Mark and Baker, Paul. "Issue Four: Can Sovereignty Coexist with Canadian Sovereignty?: Introduction." in Crosscurrents: Contemporary Political Issues. $4^{\text {th }}$ ed. (Toronto: Nelson Inc., 2002). 78-80. 
Flanagan, Thomas. "Does Anyone Really Want an Aboriginal Archipelago?" in Mark Charlton and Paul Barker, eds., Crosscurrents: Contemporary Political Issues. $4^{\text {th }}$ ed. (Toronto: Nelson Inc., 2002), 85-92.

Johnston, Larry. Politics: An Introduction to the Modern Democratic State. $2^{\text {nd }}$ ed. (Toronto: Broadview Press, 2001).

Kymlicka, Will. Finding our Way: Rethinking Ethnocultural Relations in Canada. (Toronto: Oxford University Press, 1998), 2-3 and 6-7 and 130-147.

Meekison, Peter, J.. "The Amending Formula." In Olling, R.D. and Westmacott, M.W. Perspectives on Canadian Federalism. (Scarborough: Prentice-Hall Canada Inc., 1988) 61-76.

Nichols, Roger L. Indians in the United States and Canada: A Comparative History. (Lincoln: University of Nebraska Press, 1998), 285-324.

Paine, Thomas. in The Oxford Dictionary of Quotations. $2^{\text {nd }}$ ed. (London: Oxford University Press, 1953), 373:1.

Scott, Jeffery, "Australian Federalism Renewed," in Allan Patience and Jeffery Scott, eds., Australian Federalism: Future Tense. (New York: Oxford University Press, 1983).
Sharmann, Campbell. "Fraser, the States and Federalism." in Allan Patience and Jeffrey Scott, eds., Australian Federalism: Future Tense. (New York: Oxford University Press, 1982).

Stevenson, Garth. "The Division of Power." in Olling, R.D. and Westmacott, M.W Perspectives on Canadian Federalism. (Scarborough: Prentice-Hall Canada Inc., 1988), 35-60.

Turpel, Mary Ellen, “The Charlottetown Discord and Aboriginal Peoples' Struggle for Fundamental Political Change.” In Kenneth Mc Roberts and Patrick Monahan, eds., The Charlottetown Accord, the Referendum and the Future of Canada. (Toronto: University of Toronto Press Inc., 1993), 117 145.

Verney, Douglas V. "Federalism, Federative Systems, and Federations: The United States, Canada and India." Publius. (Vol. 25, No. 2, Winter 1995) 81-95.

Watts, Ronald, L. Comparing Federal Systems. $2^{\text {nd }}$ ed. (Kingston: McGill-Queen's University Press, 1999) 6

Wheare, K.C. Federal Government. $4^{\text {th }}$ ed. (Toronto: Oxford University Press, 1963) 